\title{
Culture, eating behavior, and infectious disease control and prevention
}

Mingzhu Zhou ${ }^{1,2}, \mathrm{Na}_{\text {Zhang }}{ }^{1,2}$, Man Zhang ${ }^{1,2}$ and Guansheng Ma ${ }^{1,2^{*}}$

\begin{abstract}
Humans need to obtain nutrients from foods for survival and health. Culture and belief play important roles in food selection and intake. Throughout human history, dietary factor has been one of the important factors inducing and causing outbreaks of infectious diseases. If unhealthy eating behavior, like eating raw/undercooked food or meat and products from wild animals, are not abandoned, foodborne infectious diseases will remain an important risk factor of outbreaks and epidemics. The misconception of dietary culture is one of the important factors that triggers unhealthy eating behavior. Therefore, it is vital to change people's conceptions and knowledge about what is healthy to eat, in order to completely eliminate unhealthy eating behavior and prevent the recurrence of foodborne infectious diseases. Meanwhile, many factors such as family, society, region, and religion should be involved in.

Keywords: Culture, Eating behavior, Infectious diseases
\end{abstract}

\section{Background}

Infectious diseases threaten the health of human beings and bring a serious burden of disease as well [1]. Potential pathogens causing infectious diseases are various, including prion, bacteria, viruses, fungi, rickettsia, spirochete, and parasites $[2,3]$. It is estimated that 17 million people die worldwide each year from infectious diseases [4]. Collectively, AIDS, tuberculosis, malaria, hepatitis, and neglected tropical diseases accounted for an estimated 4.3 million deaths in 2016 [5]. Certainly, the emergence and transmission of infections is usually linked with a number of factors [6], such as age [7], gender [8], occupation [9], education level [10], personal behavior [11], climate [12], geographical condition [13], hygienic condition, economic condition [14], massive urbanization, and cultural custom. Since the twenty-first century, a total of seven public health emergencies have been identified by the World Health Organization (WHO) as Public Health Emergency of International

\footnotetext{
*Correspondence: mags@bjmu.edu.cn

'Department of Nutrition and Food Hygiene, School of Public Health, Peking University, 38 Xue Yuan Road, Hai Dian District, Beijing 100191, China

${ }^{2}$ Laboratory of Toxicological Research and Risk Assessment for Food Safety,

Peking University, 38 Xue Yuan Road, Hai Dian District, Beijing 100191, China
}

Concern (PHEIC), and five of them were associated with eating factors. Thus, it can be seen that eating behavior plays a significant part in the occurrence of infectious diseases. It is meaningful to change people's conceptions and knowledge about dietary culture and eating behavior.

\section{Changes in dietary culture and eating behavior}

Before human beings learned to use fire, they had spent a long time in the dark. In the primitive life of picking and hunting, everything they ate was raw and grasped directly by hand, including birds and animals, clams and fish, stems, leaves, and fruits. The use of fire opened the door to civilization and gave birth to our human unique culinary skills. Ancient humans ate food cooked by natural fire by accident and found that it was more delicious than raw food, and since then, natural fire was used. Finally, they knew how to create fires through long-term attempts, and learned how to control fire and cook with fire. At the very beginning, people put food directly on the fire. Then, they learned to use a medium to conduct heat in order that the food was evenly heated, such as placing the food on a hot stone, or packing the food with grass or mud or animal skin before

(c) The Author(s). 2020 Open Access This article is licensed under a Creative Commons Attribution 4.0 International License, which permits use, sharing, adaptation, distribution and reproduction in any medium or format, as long as you give appropriate credit to the original author(s) and the source, provide a link to the Creative Commons licence, and indicate if changes were made. The images or other third party material in this article are included in the article's Creative Commons licence, unless indicated otherwise in a credit line to the material. If material is not included in the article's Creative Commons licence and your intended use is not permitted by statutory regulation or exceeds the permitted use, you will need to obtain permission directly from the copyright holder. To view a copy of this licence, visit http://creativecommons.org/licenses/by/4.0/ 
using the fire to burn it, or burying the raw materials in the hot ashes or stones to make it cooked. Gradually, cooking utensils emerged during the labor practices, and various ways to preserve and store food were invented.

Backer has mountain, draft relying on water; there are huge differences in dietary culture among different regions around the world. More than 2400 years ago, the Chinese medicine classics the Yellow Emperor's Internal Classics (Huang Di Nei Jing) proposed grain for raising, fruits for help, meats for benefit, and vegetables for supplement; various foods cannot conflict with each other, so as to replenish vital energy, and grain, meat, and vegetables can provide nutrients, but they cannot be eaten too much, so as not to damage the body. This may be the earliest dietary guideline in the world. The ancient Greek Hippocrates stated that health can only be ensured by proper diet and hygiene and to treat your food like medicine, not your medicine like food. Each nation has its own set of standardized eating etiquette in its long-term practice. Likewise, different religions have also formed their own set of dietary culture. For instance, Taoism advocates vegetarianism and less food, and stopping diet. Buddhism insists that when you get a diet, do not choose it; as long as it can support your body and you can practice the Tao, it is in line with the Buddha. Islamic diet generally follows the standards of beauty and ugliness, good and evil, and cleanliness and pollution. There are also corresponding eating activities and specific food in specific festivals, emphasizing the promotion of festival atmosphere and so on, for example, turkey for Christmas in America, and dumplings for the Spring Festival in China.

Nowadays, dietary culture has developed by leaps and bounds. Modern science and technology are used to improve, cultivate, and produce new varieties of cooking raw materials, and promote and create new cooking tools. A new system has formed for modern dietary culture. People are pursuing both color and taste while paying attention to nutrition. However, some unhealthy eating behavior effected by dietary culture and beliefs still exists, such as eating raw/underprepared food or meat and products from wild animals, which could bring risks to human health.

\section{Eating behavior and infectious diseases}

Reasonable eating behavior can provide adequate and balanced nutrition to our body. However, unhealthy eating behavior is closely related to the occurrence of diseases, not only chronic non-communicable diseases, but also infectious diseases. A number of studies have shown that unhealthy eating behavior has a certain impact on the occurrence and development of infectious disease as well as prevention and control, which is noteworthy. For example, consumption of rare or underprepared food is an important cause of infectious diseases.

With the improvement of living conditions, more people no longer seek to eat full, but to eat healthy. For example, it has become increasingly popular to eat raw food, marinated food, and drunk food, including meat products, aquatic products, and plant-based products, seafood in particular, which make a great contribution to foodborne infectious diseases.

To maintain the food's quality, especially its delicious taste, people in some places like to eat raw food. They believe that fresh food has the richest nutrition and the best taste, and the best consumption period of any food is when its vitality is at its peak. Consumption of raw and improperly cooked food is very common in South and Southeast Asia [15]. For example, in Japan, where seafood resources are abundant and raw food culture is popular, more than $70 \%$ of foodborne illnesses have been linked to seafood [16], and about 1000 cases of anisakiasis are reported every year. In addition, some traditional cuisine believes that food processing technology should be minimized, and food should be eaten as close to the nature state as possible so that food could maintain its highest nutritional value. Nevertheless, there are huge health risks associated with raw or underprepared food, such as bacteria, viruses, parasites, or toxin and allergen. A number of varieties of parasites, including nematodes, trematodes, cestodes, cestodes, and protozoa [17], and viruses and bacteria, like human caliciviruses, hepatitis A virus, vibrio species, and Streptococcus suis, have been reported to cause infection outbreaks related to consumption of raw food, which can be seen all around the world. A case study in the lower Northern Thailand [18] found that daily consumption of raw fish averaged a 3.12-3.60 times higher risk of a liver fluke Opisthorchis viverrini infection compared to those with no raw fish eating habit. A report of hepatitis $E$ infection in Jordan [19] showed that eating underprepared meat was significantly associated with HEV seropositivity (OR 2.06; 95\% CI 1.04, 4.06). Park et al. [20] concluded that the habit of eating raw fish was the major factor for the maintenance of clonorchiasis among residents of riverside areas in Muju-gun, Jeollabuk-do, Korea; the odds ratio of residents who had eaten raw fish was 3.2-fold higher than that of those who had not.

Fish-borne zoonotic nematodes could infect human beings when fish or other aquatic products are consumed live, raw, smoked, or lightly cooked. In South America, potentially zoonotic nematode species are very common; infection with all kinds of nematodes was reported. Most of these cases were from countries such as Peru, Chile, and Ecuador where people have a tradition of eating raw or inadequately cooked aquatic products as in the form of the traditional dish called "ceviche." 
Another important form was the raw fish prepared according to traditional Japanese dishes, like "sushi" (Fig. 1) and "sashimi" (Fig. 2) [21].

Clonorchiasis, also known as liver fluke disease, is endemic in China, Korea, Vietnam, and Japan. People at any age can be infected. It was one of the most serious foodborne parasitic diseases in China at the beginning of the twenty-first century. It was estimated that 35 million people worldwide were infected, of which about 15 million people in China [22]. Totally, 62 counties and cities have reported an epidemic of clonorchiasis in Guangdong province, China, and the most severe epidemic areas were mainly distributed in the Pearl River Delta region, especially Jiangmen [23]. The infection rate was $21.77 \%$ in Jiangmen, and it could reach $78.8 \%$ in some rural areas in 2007 [24]. Eating sashimi or raw or lightly cooked shrimp was the main risk factor related to clonorchis infection. Infection rate was higher in males, the reasons for which were indistinct but may be related to more opportunities of outside eating for males. Moreover, sashimi was often used as a treat to entertain relatives and friends, which further expanded the infection. Likewise, liver fluke disease is highly prevalent in rural southern Laos where raw food consumption had a deep cultural root. Their misunderstandings about health risks of raw food consumption were widespread. Raw fish with a "sour juice" made from squeezed adult weaver ants and spices like salt was considered to be equal to cooked fish. It was a long-standing tradition to use raw fish in various dishes, and the Laotians argued that eating these raw fish dishes means to keep the bonds of friendship and kinship [25]. Also, local people claimed that these dishes can supply them with strength and energy which were prerequisite for hard physical

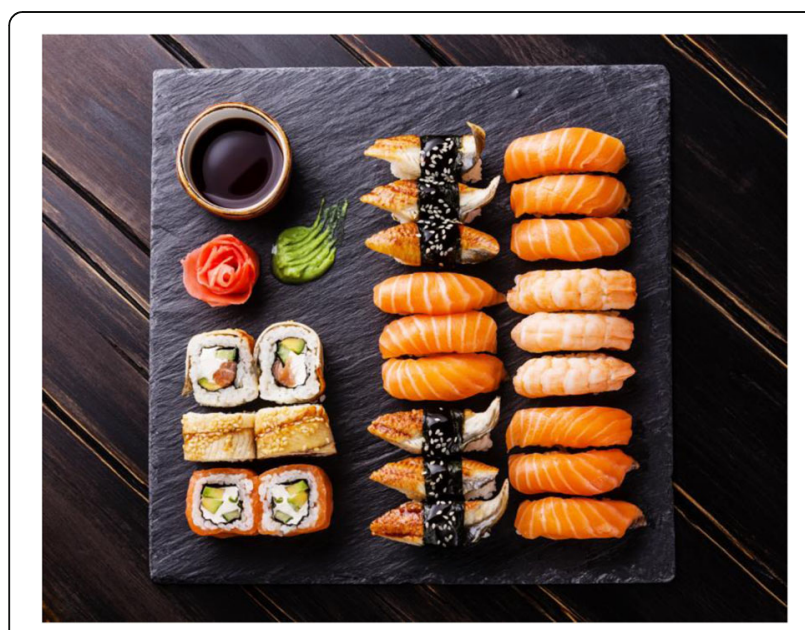

Fig. 1 "Sushi". Sushi is a traditional Japanese dish, usually made by cutting fresh sea urchin yellow, abalone, peony shrimp, scallops, salmon roe, cod roe, tuna, salmon, and other seafood into slices and placing them on the rice ball

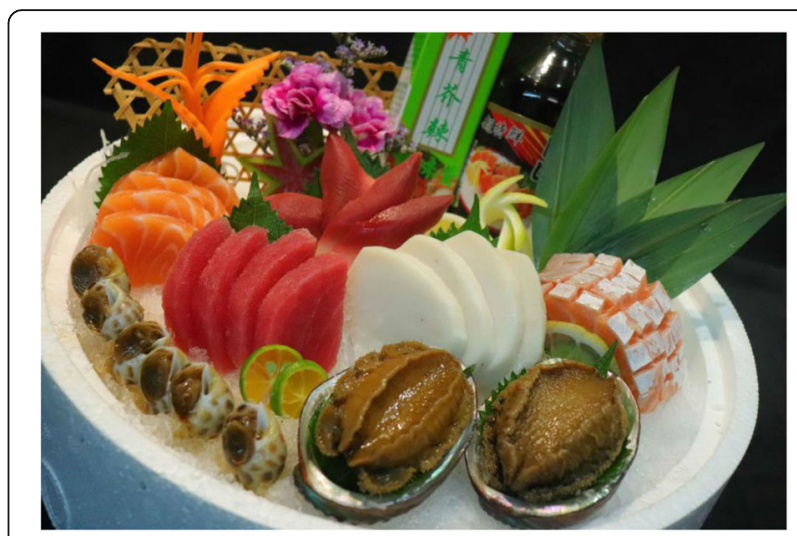

Fig. 2 "Sashimi". Sashimi is a fish dish in which fresh fish and shellfish are sliced and eaten directly with a sauce

work. In addition, these dishes were usually prepared and served at many important social and cultural festivities or religious ceremonies where it was socially unacceptable to refuse to eat them [26].

Hepatitis A virus (HAV) is a single-stranded RNA virus surrounded by a protein capsid. The outbreaks of hepatitis A virus infection has happened worldwide [27], like Sweden, the USA, Australia, Italy, and so on. The infection was transmitted through contaminated water and foods via the fecal-oral route [28], and the largest raw seafood-related epidemic was reported from Shanghai, China. During the first quarter of 1988, an unprecedented major epidemic of hepatitis A occurred in Shanghai, China. Over 300,000 cases were reported, of which $47(0.015 \%)$ were fatal [29]. This outbreak was traced to consumption of raw clams which was contaminated by domestic sewage and excrement [30]. A species of clams called Anadara subcrenata lischke was considered as the source of infection, which was supplied and transported from Qidong County, Jiangsu Province, where high incidence of hepatitis A was reported [31]. It was believed that the clams with some blood were more delicious. Eaten immediately after it was dipped in hot water, Shanghai's blood clams reportedly had a raw, briny taste that stands out in a dietary culture that was all about freshness and mouth feel. However, this simple cooking was obviously not enough to kill the germs, so the bacteria and hepatitis A virus adsorbed on the gills of the clams invaded their digestive tract and liver easily.

Cysticercus is the larva of the tapeworm Taenia solium and can cause cysticercosis in humans through intake of raw or underprepared pork contaminated with mature cysts [32]. Cysticercosis has been classified as one of the most important global foodborne parasites. Yunnan province is a serious cysticercosis epidemic area in China [33]. Local people have a habit of eating raw or undercooked pork or liver, which plays a decisive role in the spread of the disease. Some festival dishes in the 
minority areas of Yunnan province are made of raw pork, such as the "shengpi"(生皮) (Fig. 3) of Bai nationality, the "duosheng"(剁生) of Dai nationality, and the “oru”(噢嚅) (Fig. 4) of Hani nationality. The Bai people do not use boiling water but fire to kill pigs; they put the whole pig with fur on the fire until the fur is charred and scraped off, then cut the meat into thin slices and eat with seasoning (Fig. 5), which is called "Shengpi"(生 皮). “Duosheng”(槑生) is a raw meat paste with seasoning. "Oru”(噢嚅) is cold vegetables with raw pork. In 2003, 4533 cysticercosis cases were found in Yunnan from hospitals which were at or above the county level, of which the Bai people accounted for $57.73 \%$ cases [34]. The previous studies found that $80.29 \%$ of the 1086 cysticercosis cases had a history of eating uncooked meat products [35], and $93.10 \%$ of the 1696 hospitalized cases of cysticercosis had a history of eating "shengpi"(生皮) [36]. According to survey, nearly $80 \%$ of the fresh pork purchased was used to make "shengpi"(生皮) in their daily life in a village of Dali, Yunnan province [37].

Streptococcus suis is a gram-positive strain of pathogenic bacteria and a pathogenic zoonotic factor [38]. In Vietnam, Streptococcus suis infection was one of the most common cause of acute bacterial meningitis in adults [39]. There was a dish called "tiet canh" (raw blood pudding) which was acclaimed wildly in Vietnam [3]. The major ingredients of "tiet canh" were raw pig blood and other animals' blood mixed with minced pork tissues. Streptococcus suis was a common bacteria in "tiet

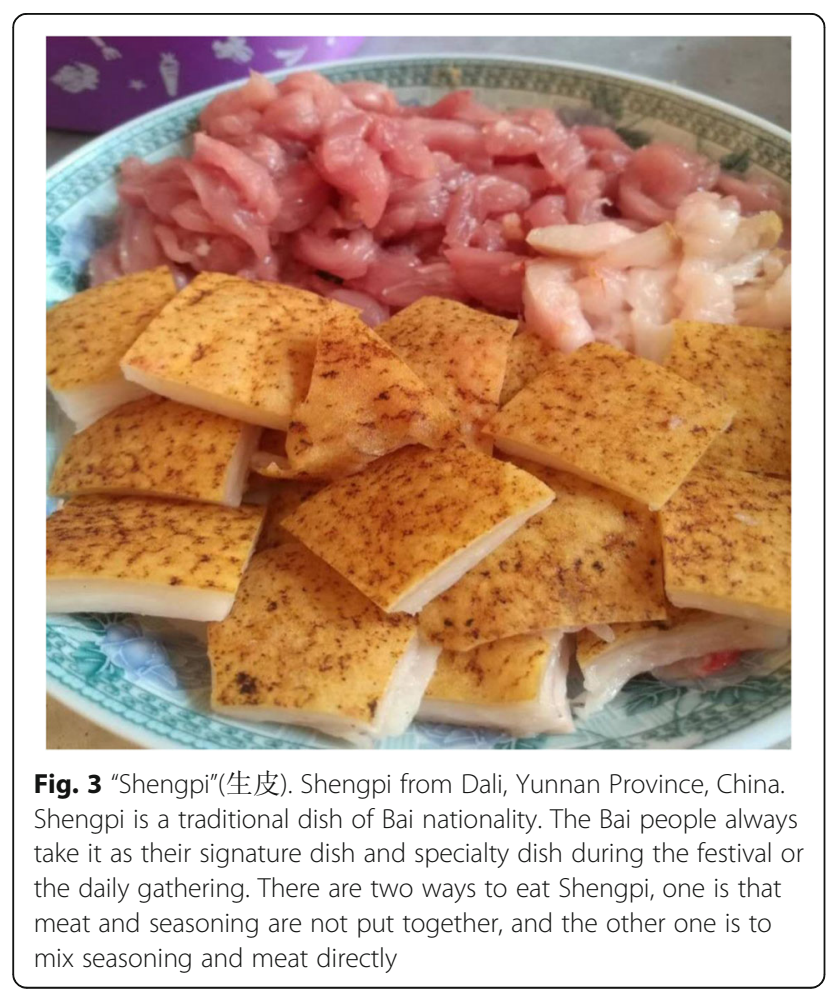

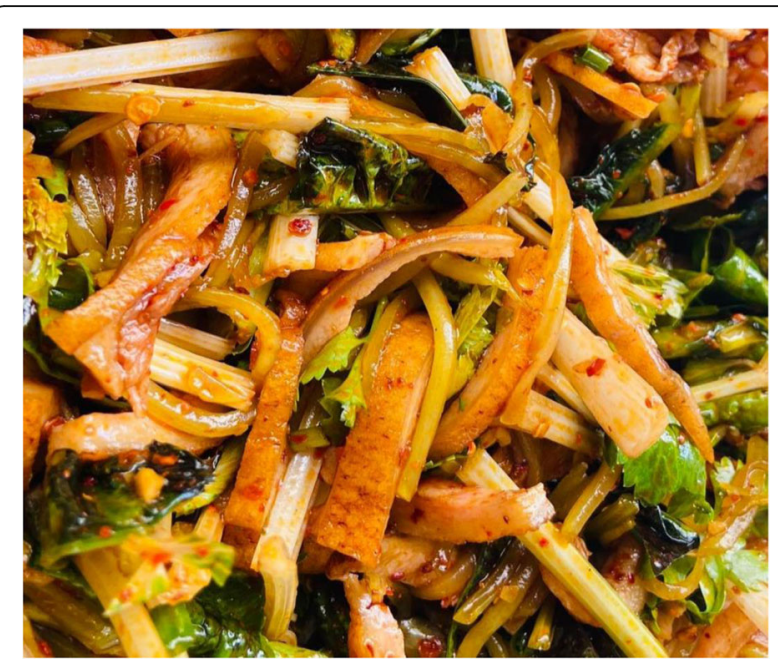

Fig. 4 "Oru"(噢嚅). Oru from Hani nationality of Yunnan Province, China. It is cold vegetables with raw pork

canh" [40]. A case-control study conducted between May 2006 and June 2009 showed that risk factors identified for Streptococcus suis infection included eating "high risk" dishes such as undercooked pig blood (OR 2.22; 95\% CI 1.15, 4.28) and pig intestine (OR 4.44; 95\% CI 2.15 , 9.15) [41]. In 2015, five swine streptococcus infections cases were reported, three of which were caused by eating raw blood pudding.

It is shocking to know that $75 \%$ of emerging infectious diseases originated from animals and no less than twothirds of these originated in wildlife [42]. In modern

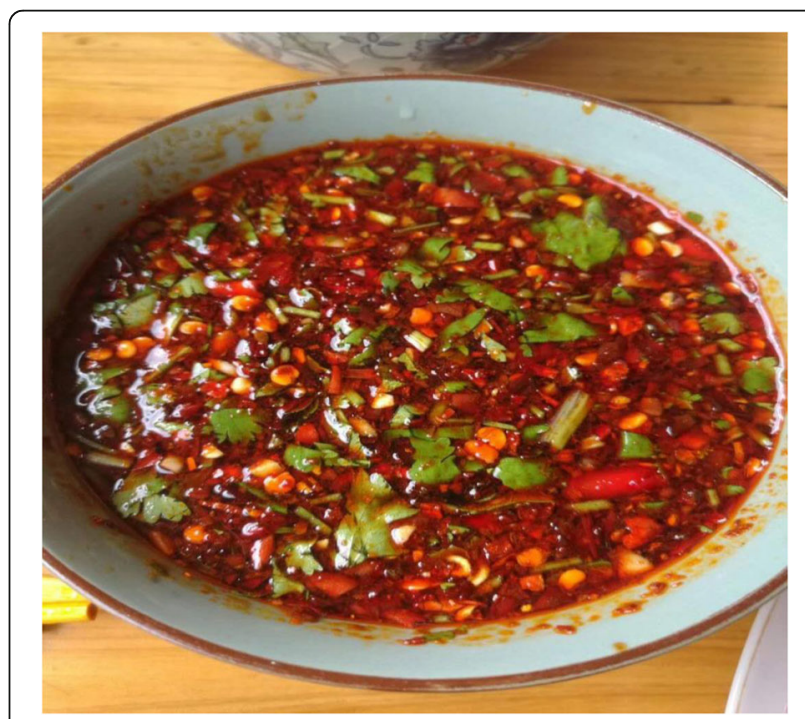

Fig. 5 Seasoning. Seasoning is the soul of Yunan cuisine. The ingredients in it are not fixed but can be added or removed according to one's taste. In general, seasoning includes pepper, star anise powder, chili powder, sesame powder, coriander, chives, and ginger 
times, though meat from wild animals is not needed for survival and it should not be part of dietary culture and modern civilization, the tradition of eating it persists in some places. The obsession with rare meat/animal products may stem from the philosophy of medicine food homology and the idea of when a thing is rare, it becomes precious. Many people mistakenly think that meat and products from wild animals not only taste good but also have nourishing effects. For example, penis of a deer is believed to have aphrodisiac effect, and the brain of some wild animals is supposed to make people smarter. Another false belief often held is that meat and products from wild animals have certain therapeutic effects. For instance, pangolin meat is believed to help relieve rheumatism; the bile of snakes is believed to improve eyesight. The spread of such misconceptions has made many people fall into a superstitious and inextricable zone. Meanwhile, rare and expensive food can be used by people to express wealth and social status [43]. The consumption of these foods seems to be more "characteristic" and "upper-grade," so consumers have a display of economic capacity and social status, and their vanity is greatly satisfied.

Due to exposure to the wild and lack of quarantine, wild animals often carry a variety of bacteria and viruses and other pathogens. During the process of capturing and eating, these pathogens can be taken to human beings. More than 1400 kinds of pathogens are known to be able to infect humans. Among them, nearly $61 \%$ of the pathogens come from wild animals [44]. For example, bats can carry more than 130 highly pathogenic viruses [45], like lyssaviruses, Hendra virus, Nipah virus, coronaviruses, Ebola, and Marburg viruses. Moreover, humans in Africa are still exposed to a possibility of being infected by diseasecausing microbes from wildlife via hunting and handling of bushmeat [46]. Bushmeat is a general term for "game" from the tropics, mainly referring to West and Central Africa. The meat is not from poultry or livestock, but directly from wild animals such as primates, rodents, or fruit bats found in tropical jungles. Tropical forests are known for their abundance of species, but these animals carry a great number of pathogenic microorganisms. Acquired immune deficiency syndrome (AIDS), for example, can be traced to chimpanzees [47].

Trichinellosis is a worldwide foodborne parasitic zoonotic disease caused by nematodes of the genus Trichinella, which are widespread globally in wildlife. Human infections are strictly related to cultures, where dietary habits include consumption of meat from wild animals. Many cases of trichinellosis have been reported in the Arctic (North Quebec, Nunavut, and Greenland) due to eating meat and products from black, brown, or polar bears [48]. In November 2014, a large outbreak of trichinellosis occurred in Belgium, related to the consumption of imported wild boar meat [49]. In 2011, an outbreak of trichinella infections associated with wild boar hunted at a game farm was reported in Iowa [50]. Growing interest in consuming wild boar has the potential to expose more individuals to this disease. In many Asian countries, many people were fond of eating meat and viscera of raw wild animals. This eating habit was one of the important factors in the transmission of taeniasis. Infections have been reported in Taiwan Province of China, Cheju Island of Korea, and Ambarita District on Samosir Island from 1984 to 1989. Among infected Taiwan aborigines, 73\% had eaten wild boar, $66 \%$ flying squirrel, $65 \%$ wild goat, $56 \%$ muntjac, $49 \%$ wild rats, $46 \%$ monkey, $38 \%$ hare, $20 \%$ civet cats, $18 \%$ weasel, $17 \%$ pheasant, $14 \%$ squirrel, $4 \%$ grouse, $1 \%$ deer, $1 \%$ snake, less than $1 \%$ bamboo partridge, less than $1 \%$ frog, less than $1 \%$ bear, less than $1 \%$ dog, and less than 1\% fox [51]. Furthermore, a case of Escherichia coli $\mathrm{O} 157: \mathrm{H} 7$ infection acquired by eating wild whitetailed deer was found in Connecticut [52]. And evidence suggested that eating wild boars is associated with a high risk of acquiring hepatitis $\mathrm{E}$ infection [53].

\section{Summary}

Unhealthy eating behavior is related to the incidence and spread of some infectious diseases. Therefore, changing unhealthy eating behavior and practicing healthy eating behavior are very important in preventing and controlling the spread of infectious diseases. Some behaviors and habits may have been passed on from generation to generation, influenced by culture and beliefs. Obviously, it is difficult to change them completely within a short time, we need to make effort from multiple aspects, and special attention needs to be paid to the role of culture and beliefs. The ultimate solution lies in changing people's conceptions about what is delicious, trendy, prestigious, or healthy to eat. Consequently, it is vital to popularize and spread healthy and scientific knowledge about diet to guide people to form the correct concept and develop healthy and scientific eating habits and lifestyles. Likewise, it is necessary to strengthen the cultivation and establishment of scientific and healthy food consumption concepts in early childhood. We can embed scientific diet into diet-related knowledge systems such as food education curriculum to help children establish a scientific and healthy food consumption concept as soon as possible.

\section{Acknowledgements \\ Not applicable.}

Authors' contributions

Mingzhu Zhou wrote this manuscript. Na Zhang, Man Zhang, and Guansheng Ma revised the manuscript. All authors read and approved the final manuscript. 


\section{Funding}

There is no fund.

\section{Availability of data and materials}

Not applicable.

\section{Competing interests}

There is no competing interest for all authors.

Received: 5 May 2020 Accepted: 18 November 2020

Published online: 25 November 2020

\section{References}

1. Christou L. The global burden of bacterial and viral zoonotic infections. Clin Microbiol Infec. 2011;17(3):326-30.

2. Weis AM, Storey DB, Taff CC, Townsend AK, Huang BC, Kong NT, et al. Genomic comparison of Campylobacter spp. and their potential for zoonotic transmission between birds, primates, and livestock. Appl Environ Microbiol. 2016;82(24):7165-75.

3. Chu D, Ngoc TU, Chu-Dinh T, Ngoc VTN, Van Nhon B, Pham V, et al. The possible zoonotic diseases transferring from pig to human in Vietnam. Eur J Clin Microbiol. 2019;38(6):1003-14.

4. Sarma N. Emerging and re-emerging infectious diseases in South East Asia. Indian J Dermatol. 2017;62(5):451-5.

5. World Health Statistics 2019. https://www.who.int/gho/publications/world_ health_statistics/2019/en/. Accessed 15 Apr 2020.

6. Mani RS, Ravi V, Desai A, Madhusudana SN. Emerging viral infections in India. Proc Natl Acad Sci India B Biol Sci. 2012;82:5-21.

7. Yoshikawa T. Important infections in elderly persons. Western J Med. 1981; 135(6):441-5.

8. Henrique-Araújo R, Quarantini LC, Morais-de-Jesus M, Jesus-Nunes AP, Dantas-Duarte A, Caribé AC, et al. Comparative study of impulsiveness and risk behaviors among infected individuals with hepatitis $C$ virus and human T-cell lymphotropic virus type 1. Ann Hepatol. 2020;19(2):166-71.

9. Fukusumi M, Kanagawa Y, Ohfuji S, Miyazaki K, Matsui T, Mizoguchi K, et al. Risk of seasonal influenza by occupation in a railway company in a metropolitan area of Japan during three influenza seasons. Jpn J Infect Dis. 2020.

10. Hassan BM, Baig MA. Determinants of respiratory infections among children under 5 years in Islamabad, Pakistan. J Infect Public Heal. 2020;13(3):465.

11. Mahmoudvand H, Badparva E, Khalaf AK, Niazi M, Khatami M, Nazer MR. Prevalence and associated risk factors of intestinal helminthic infections in children from Lorestan province, Western Iran. Parasite Epidemiol Contr. 2020;9:e00136.

12. Liang L, Gong P. Climate change and human infectious diseases: a synthesis of research findings from global and spatio-temporal perspectives. Environ Int. 2017;103:99-108

13. Lee $\mathrm{G}$, Cho I, Lee $Y$, Hoh H, Shin D, Lee S, et al. Epidemiological study of clonorchiasis and metagonimiasis along the Geum-gang (river) in Okcheongun (county), Korea. Korean J Parasitol. 2002;40(1):9-16.

14. Liu Q, Xu W, Lu S, Jiang J, Zhou J, Shao Z, et al. Landscape of emerging and re-emerging infectious diseases in China: impact of ecology, climate, and behavior. Front Medprc. 2018;12(1):3-22.

15. Grundy-Warr C, Andrews RH, Sithithaworn P, Petney TN, Sripa B, Laithavewat $L$, et al. Raw attitudes, wetland cultures, life-cycles: socio-cultural dynamics relating to Opisthorchis viverrini in the Mekong Basin. Parasitol Int. 2012 61(1):65-70.

16. Scoging AC. Illness associated with seafood. Can Med Assoc J. 2003;147: 1344-7.

17. Butt AA, Aldridge KE, Sander CV. Infections related to the ingestion of seafood. Part II: parasitic infections and food safety. Lanect Infect Dis. 2004; 4(5):294-300.

18. Pumidonming $W$, Katahira $H$, Igarashi M, Salman D, Abdelbaset AE, Sangkaeo K. Potential risk of a liver fluke Opisthorchis viverrini infection brought by immigrants from prevalent areas: a case study in the lower Northern Thailand. Acta Trop. 2018;178:213-8.

19. Obaidat MM, Roess AA. Seroprevalence and risk factors of Hepatitis $E$ infection in Jordan's population: First report. Int J Infect Dis. 2018;66:121-5.

20. Park D, Na S, Cho SH, June KJ, Cho Y, Lee Y. Prevalence and risk factors of Clonorchiasis among residents of riverside areas in Muju-gun, Jeollabuk-do, Korea. Korean J Parasitol. 2014;52(4):391-7.
21. Eiras JC, Pavanelli GC, Takemoto RM, Nawa Y. Fish-borne nematodiases in South America: neglected emerging diseases. J Helminthol. 2018;92(6):649-54.

22. Liu YH, Yin BK, Zheng NC, et al. Investigation of the epidemiological characteristic of Clonorchiasis in Jiangmen Pengjiang District. J Trop Med. 2012;12(11):1385-7.

23. Fang $Y Y$, Wu J, Liu Q, et al. Investigation and analysis on epidemic status of clonorchiasis in Guangdong Province, China. J Pathog Biol. 2007;01:54-6.

24. Yin $Q$, Yang F, Wang BH, et al. Survey of clonorchiasis in Fuyu County in 2009. Chin J Schistosomiasis Contr. 2011;23(05):598.

25. Weichart G, van Eeuwijk P. Food chains: eating, drinking, feeding-framing social relations. Preface. Anthropol Food. 2008;S3:1-5.

26. Xayaseng $V$, Phongluxa K, van Eeuwijk P, Akkhavong K, Odermatt P. Raw fish consumption in liver fluke endemic areas in rural southern Laos. Acta Trop. 2013;127(2):105-11.

27. Butt AA, Aldridge KE, Sanders CV. Infections related to the ingestion of seafood Part I: viral and bacterial infections. Lancet Infect Dis. 2004;4(4):201-12.

28. Wanke CA, Guerrant RL. Viral hepatitis and gastroenteritis transmitted by shellfish and water. Infect Dis Clin North Am. 1987;1:649-64.

29. Cooksley WGE. What did we learn from the Shanghai hepatitis A epidemic? J Viral Hepatitis. 2000;7(1):1-3.

30. Xu Z, Li Z, Wang J, Xiao Z, Dong D. Ecology and prevention of a shellfishassociated hepatitis A epidemic in Shanghai, China. Vaccine. 1992;10(1):S67-8.

31. Tang YW, Wang JX, Xu ZY, Guo YF, Qian WH, Xu JX. A serologically confirmed, case-control study, of a large outbreak of hepatitis a in China, associated with consumption of clams. Epidemiol Infect. 1991;107(3):651-7.

32. Sithole MI, Bekker JL, Mukaratirwa S. Consumer knowledge and practices to pork safety in two Taenia solium cysticercosis endemic districts in Eastern Cape Province of South Africa. BMC Infect Dis. 2020;20(1):107-8.

33. $X u L Q$, Jiang $Z X$, Zhou $C H$, et al. Investigation on the distribution of cysticercosis in China. J Pathog Biol. 1999;01:35-7.

34. Dong $Y$, Zhang ZX. A review of human parasitic disease prevalence in Yunnan Province, China. J Pathog Biol. 2009:4(08):626-32.

35. Luo TP, Zhao YJ. Analysis of 1086 cases of cysticercosis in Dali, Yunnan Province. Parasitoses Infect Dis. 1998:02:87-8.

36. Fang W. Epidemiological analysis of taeniasis/cysticercosis during 1986-1998 in Dali prefecture. J Pathog Biol. 2001(02):39-41.

37. Fang W, Lian ZQ, Fang C. Investigation on epidemic factors of taeniasis and cysticercosis in Bai Nationality in Leiyi Village, Dali Prefecture. J Pathog Biol. 1995;03:199

38. Wertheim HF, Nghia HD, Taylor W, Schultsz C. Streptococcus suis: an emerging human pathogen. Clin Infect Dis. 2009;48(5):617-25.

39. Mai NTH, Hoa NT, Nga TVT, Chau TTH, Sinh DX, Phu NH, et al. Streptococcus suis meningitis in adults in Vietnam. Clin Infect Dis. 2008;46(5):659-67.

40. Huong VTL, Hoa NT, Horby P, Bryant JE, Van Kinh N, Toan TK, et al. Raw pig blood consumption and potential risk for Streptococcus suis infection, Vietnam. Emerg Infect Dis. 2014;20(11):1895-8.

41. Dang TNH, Thi PTL, Wolbers M, Quang TC, van MHN, Vu TNT, et al. Risk factors of Streptococcus suis infection in Vietnam. A Case-Control Study. PLOS ONE. 2011:6(3):e17604.

42. Vorou R, Papavassiliou V, Tsiodras S. Emerging zoonoses and vector-borne infections affecting humans in Europe. Epidemiol Infect. 2007;135(8):1231-47.

43. Ma G. Food, eating behavior, and culture in Chinese society. J Ethnic Foods. 2015:2(4):195-9.

44. Taylor LH, Latham SM, Woolhouse ME. Risk factors for human disease emergence. Philos T R Soc B. 2001;356(1411):983-9.

45. James L, Wood N, Leach M, Waldman L, MacGregor H, Fooks AR, Jones KE, et al. A framework for the study of zoonotic disease emergence and its drivers: spillover of bat pathogens as a case study. Philos Trans Biol Sci. 2012;367(1604):2881-92.

46. Van Heuverswyn F, Peeters M. The origins of HIV and implications for the global epidemic. Curr Infect Dis Rep. 2007;9(4):338-46.

47. Sharp PM, Hahn BH. Origins of HIV and the AIDS pandemic. CSH Perspect Med. 2011;1(1):a006841.

48. Dupouy-Camet J, Yera H, Dahane N, Bouthry E, Kapel CMO. A cluster of three cases of trichinellosis linked to bear meat consumption in the Arctic. J Travel Med. 2016;23(5):taw037.

49. Messiaen P, Forier A, Vanderschueren S, Theunissen C, Nijs J, van Esbroeck $M$, et al. Outbreak of trichinellosis related to eating imported wild boar meat, Belgium, 2014. Eurosurveillance. 2016;21(37):2-9.

50. Holzbauer SM, Agger WA, Hall RL, Johnson GM, Schmitt D, Garvey A, et al. Outbreak of Trichinella spiralis infections associated with a wild boar hunted at a game farm in lowa. Clin Infect Dis. 2014;59(12):1750-6. 
51. Fan $P C$, Fan $P C$, Chung WC, Chung WC, Soh CT, Soh CT, et al. Eating habits of East Asian people and transmission of taeniasis. Acta Trop. 1992;50(4): 305-15.

52. Rabatsky-Ehr T, Dingman D, Marcus R, Howard R, Kinney A, Mshar P. Deer meat as the source for a sporadic case of Escherichia coli 0157:H7 infection, Connecticut. Emerg Infect Dis. 2002;8(5):525-7.

53. Masuda JI, Yano K, Tamada Y, et al. Acute hepatitis E of a man who consumed wild boar meat prior to the onset of illness in Nagasaki, Japan. Hepatol Res. 2005;31(3):178-83.

\section{Publisher's Note}

Springer Nature remains neutral with regard to jurisdictional claims in published maps and institutional affiliations.

Ready to submit your research? Choose BMC and benefit from:

- fast, convenient online submission

- thorough peer review by experienced researchers in your field

- rapid publication on acceptance

- support for research data, including large and complex data types

- gold Open Access which fosters wider collaboration and increased citations

- maximum visibility for your research: over $100 \mathrm{M}$ website views per year

At BMC, research is always in progress.

Learn more biomedcentral.com/submissions 